\title{
Clostridium Botulinum C3 Exoenzyme: Rho-Inactivating Tool in Cell Biology and a Neurotrophic Agent
}

\author{
Ingo Just*, Stefanie C. Huelsenbeck and Harald Genth
}

Department of Toxicology, Hannover Medical School, Germany

\begin{abstract}
C3 exoenzyme from Clostridium botulinum is the prototype of bacterial ADP-ribosyltransferases, which selectively modifies the Rho isoforms RhoA, RhoB and RhoC by covalent attachment of an ADP-ribose moiety. ADPribosylation results in inactivation of cellular functions of Rho. Because of its highly restricted substrate specificity, C3 is an established tool in cell biology; to this end $\mathrm{C} 3$ is applied as a cell-permeable chimeric toxin. $\mathrm{C} 3$ is superior to other molecular biology techniques such as siRNA or knock down approaches as RhoA inactivation or knock down is intrinsically associated with RhoB activation except after $\mathrm{C} 3$ treatment. RhoA plays an essential role in axonal growth and repair after neuronal injury. For therapeutic purposes cell- permeable C3 is now locally administered to treat spinal cord injury. Recently, it was reported that ADP-ribosyltransferase activity is not essential for the neurotrophic effect of C3 and that a peptidic fragment of $\mathrm{C} 3$ acts neurotrophic.
\end{abstract}

Keywords: ADP-ribosylation, Rho, Glucosylation, Neurotrophic effect.

\section{INTRODUCTION}

C3 is produced by $C$. botulinum but is not related to the classical neurotoxins. $\mathrm{C} 3$ is an exoenzyme devoid of any attributable transport domain that is released by bacteria. Such domains are well-known delivery domains of bacterial protein toxins like cholera or pertussis toxin. The delivery domain consists of a receptor binding and translocation region that deliver the enzymic domain into the cytoplasmic compartment. Based on structural comparison, $\mathrm{C} 3$ is a mere enzyme but not a classical protein toxin. Nevertheless it reaches the cytoplasm of target cells by non specific uptake.

\section{ADP-RIBOSYLATION OF CELLULAR SUBSTRATES}

C3 catalyzes mono-ADP-ribosylation of the low molecular weight GTP-binding proteins RhoA, RhoB, and RhoC $[1,2]$. The ADP-ribose moiety from ubiquitous cellular $\mathrm{NAD}^{+}$is $\mathrm{N}$-glycosidically attached to the acceptor amino acid Asn-41 [3]. Thereby, two negatively charged phosphate groups are incorporated into the Rho protein resulting in its functional inactivation [4-6].

The substrate protein RhoA belongs to the Rho family of Ras proteins. They are guanine nucleotide-regulated monomeric GTP-binding proteins, which drive specific intracellular signalling. The Rho family is composed of several subfamilies: Rho(A,B,C), $\operatorname{Rac}(1,2,3) / \mathrm{RhoG}, \mathrm{Cdc} 42 /-$ TC10/TCL, Rnd(1,2,3), RhoH, RhoD/F. Only the highly homologous RhoA, RhoB and RhoC are substrates for C3 but not the other members. Rho, Rac, and Cdc42 are the master regulator of the actin cytoskeleton and cytoskeletonassociated functions such as cell shape, motility, phagocytosis, and smooth muscle contraction. RhoA regulates

*Address correspondence to this author at the Department of Toxicology, Hannover Medical School, Germany; Tel +49 511532 2914;

Fax +49 511 5322879; E-mail: just.ingo@mh-hannover.de formation of actin stress fibres, while Rac1 and Cdc42 control lamellipodia and filopodia formation, respectively. In addition, Rho is involved in the activation of transcription factors, cell cycle progression, cell transformation, and contractile ring formation in cytokinesis. While RhoA and RhoC are constitutively expressed, RhoB is a short-lived immediate-early gene product, which is up-regulated in response to cellular and genotoxic stress. RhoB (as well as RhoC) contributes to vesicle trafficking and cancer development [7-10].

ADP-ribosylation renders Rho incapable of down-stream signalling. Competence of down-stream signalling is governed by guanine nucleotides. Inactive, signallingincompetent RhoA is bound to GDP and localized in the cytoplasm as a complex with GDI-1 (guanuine nucleotide dissociation inhibitor-1), which stabilizes the inactive state. Activation results in release of RhoA from GDI-1 complex, translocation to the membranes and loading with GTP. Binding to GTP induces a conformational change (in switch I and II), which allows active RhoA to interact with and activate effector proteins [11]. Such proteins are kinases, lipases and scaffold proteins, which execute and amplify the Rho signal [12]. For example, activation of effector Rhokinase (ROCK) by GTP-bound RhoA results in phosphorylation of myosin to increase F-actin contractility $[7,8,13]$.

Asn-41, the acceptor amino acid of the ADP-ribose, resides in switch I, which is the effector binding region with which Rho binds to the effector protein. Interestingly, the bulky ADP-ribose does not block binding of RhoA to its effector proteins. Instead, the ADP-ribose blocks GTP loading catalyzed by the guanine nucleotide exchange factor (GEF). Furthermore, ADP-ribosylation prevents release of RhoA-GDP from the GDI-1 complex. Both sequestration to the GDI-1 complex and inhibition of GEF-induced GTPloading, entraps RhoA in an inactive GDP-bound state and 

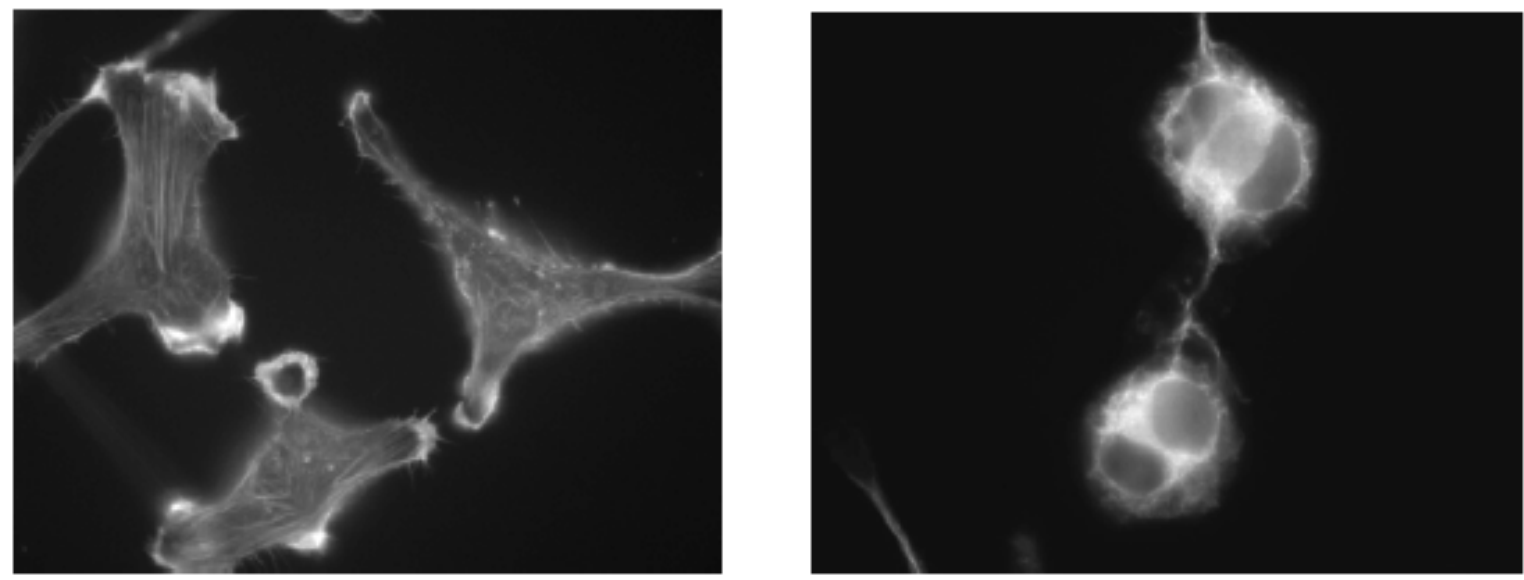

Fig. (1). C3-induced re-organization of the actin cytoskeleton. $\mathrm{C} 3^{\lim }$ was applied to Hela cells using electropermeation. After 8 h of incubation, cells were fixed and the actin cytoskeleton was visualized by rhodamine-phalloidin staining. Left panel: control, right panel: treatment with $\mathrm{C} 3$.

subsequently inhibits Rho-dependent downstream signalling [6,14-18].

The most prominent finding of cells treated with C3 exoenzyme is the disappearance of actin stress fibres and cell rounding $[2,4,19]$. The actin cytoskeleton, which can be visualized as stress fibres, lamellipodia, and filopodia, is a dynamic equilibrium between polymerizing and depolymerizing impact. Actin polymerization is triggered (among others) by the Rho effector protein Rho-kinase (ROCK). ADP-ribosylation of RhoA causes inactivation of Rho-kinase and inhibition of F-actin polymerization. In C3treated cells, the equilibrium between actin polymerizing and depolymerizing is altered and depolymerizing activity preponderates resulting in disappearance of stress fibres and altered morphology (Fig. 1). This example illustrates that GTP-binding protein-mediated signalling is not monodirectional, but rather a network in which several extra- and intra-cellular impacts are synchronized.

\section{THE FAMILY OF C3-LIKE ADP-RIBOSYLTRANS- FERASES}

C3 from C. botulinum (C3 ${ }^{\text {bot }}$ ) was the first Rho-ADPribosylating bacterial exo-enzyme described and continues as family prototype of C3-like ADP-ribosyltransferases. This family further encompasses C3 isoforms from Clostridium limosum $\left(\mathrm{C}^{\mathrm{lim}}\right)$ [20], Bacillus cereus $\left(\mathrm{C}^{\mathrm{cer}}\right)$ [21,22], and Staphylococcus aureus (C3 $\left.{ }^{\text {stau }}\right)$ [23] (Table I). The C3-like ADP-ribosyltransferases are secreted by means of a signal peptide and, thus, are classical bacterial exo-enzymes. The overall identity is about $35 \%$ but all C3 isoforms harbour highly conserved motifs: The ARTT motif (ADPribosylation toxin-turn-turn loop) is involved in Rho substrate recognition and harbours the catalytic glutamic acid residue, the PN (phosphate-nicotinamide) loop is involved in binding of co-substrate $\mathrm{NAD}^{+}$, and the STS-motif which together with conserved arginine residues form the catalytic cavity [24, 25].

The $\mathrm{C}^{\text {stau }}$ isoforms differ in their substrate specificity from $\mathrm{C} 3{ }^{\text {bot }}, \mathrm{C} 3^{\mathrm{lim}}$ and $\mathrm{C} 3^{\text {cer }}$. In addition to RhoA/B/C, C3 ${ }^{\text {stau }}$ ADP-ribosylates Rnd3 also known as RhoE [23]. Rnd3/RhoE is constitutively active based on the missing GTPase activity. It is a functional antagonist of RhoA. However, modification of RhoE is poor compared to RhoA. The functional relevance of RhoE ADP-ribosylation is not clear so far [26-28].

In addition to their transferase activities, C3 isoforms can hydrolyze $\mathrm{NAD}^{+}$into ADP-ribose and nicotinamide in the absence of the protein substrate Rho. However, free ADPribose is not covalently bound to Rho nor to Rnd3/RhoE. This $\mathrm{NAD}^{+}$hydrolyzing activity is poor compared to the ADP-ribosyltransferase activity and only detectable under artificial conditions, for which reasoning suggests that the hydrolyzing activity likely does not possess biological relevance [29].

\section{NON-MODIFIED TARGETS OF C3}

C3 interacts also with a cellular target but does not enzymically ADP-ribosylate the target. Two C3 isoforms bind independently from their inherent transferase activity to

Table 1. Substrate Specificity of C3 Isoforms

\begin{tabular}{|c|c|c|c|}
\hline & Substrates & Targets & Neurotrophic \\
\hline \hline C. botulinum $\mathrm{C} 3 \mathrm{C} 3^{\text {bot }}$ & RhoA,B,C & Ral & + \\
\hline C. limosum $\mathrm{C} 3 \mathrm{C}^{\text {lim }}$ & RhoA,B,C & Ral & - \\
\hline B. cereus $\mathrm{C} 3 \mathrm{C}^{\text {cer }}$ & RhoA,B,C & - & - \\
\hline S. aureus $\mathrm{EDIN} \mathrm{C3} 3^{\text {stau }}$ & $\begin{array}{c}\text { RhoA,B,C } \\
\text { Rnd3/RhoE }\end{array}$ & - & - \\
\hline
\end{tabular}


Ral. Ral is a low molecular weight GTP-binding protein that belongs to the Ras family. Ral is involved in transformation, migration, vesicle trafficking and stress response. In a cellfree system, $\mathrm{C} 3^{\text {bot }}$ and $\mathrm{C} 3^{\lim }$ (but not $\mathrm{C} 3^{\text {cer }}$ and $\mathrm{C} 3^{\text {stau }}$ ) and Ral form a high affinity complex $\left(\mathrm{K}_{\mathrm{D}} \sim 60 \mathrm{nM}\right)$. Formation of the C3-Ral complex does not result in ADP-ribosylation of Ral. In contrast, the ADP-ribosyltransferase activity of $\mathrm{C} 3$ is blocked in the Ral complex. Vice versa, sequestration of Ral in the C3-complex blocks Ral-dependent downstream signalling. The recently determined X-ray crystallographic structure shows that $\mathrm{C} 3$ interacts with a region around switch II. Substrate recognition of Rho, however, is mediated via switch I. The interaction of C3 with switch II of Ral implicates that C3 acts like a GDI (guanine nucleotide dissociation inhibitor) to stabilize the inactive GDP-bound form of Ral to prevent GTP-exchange, i.e. activation. Thus, activation of Ral is inhibited by $\mathrm{C} 3$ through binding but not ADP-ribosylation. Whether these findings from cell-free systems are of biological relevance remains to be clarified [30,31].

\section{C3 AS A TOOL IN CELL BIOLOGY}

C3 possesses a highly-restricted substrate specificity, as only RhoA/B/C out of approximately 150 low molecular weight GTP-binding proteins are ADP-ribosylated by C3. For this reason, $\mathrm{C} 3$ is classified as an excellent tool in cell biology to study the role of RhoA in cellular functions [6, $32,33]$. This notion is still true in the era of knock-out cells and siRNA. Generation of RhoA knock-out cells is not compatible with the critical role of RhoA in contractile ring formation in cytokinesis [34]. Furthermore, application of RhoA-siRNA is accompanied by massive RhoB expression and activation [35]. This unwanted side effect is based on the fact that activity of the $r h o B$ promoter is suppressed by RhoA [35, 36]. RhoA inactivation is thus intrinsically associated with RhoB expression. Strong RhoB expression is also observed upon treatment of cells with C3 [35]. C3, however, completely ADP-ribosylates (i.e. inactivates) RhoB as well as completely inactivates RhoA [37]. Application of C3 thus represents the only approach to effectively inhibit RhoA without concomitant RhoB activation.

The application of $\mathrm{C} 3$ as a tool in cell biology is limited by its poor cell accessibility. C3 is deficient of a delivery domain to reach the cytoplasm of cells. C3 enters cell (likely by pinocytosis) upon the application of micromolar concentrations and long incubation times (up to $24-48 \mathrm{~h}$ ). [19, 38-40].

The poor cell accessibility of $\mathrm{C} 3$ is overcome by microinjection (on the single cell level) [4, 41-45] or permeabilization techniques using either digitonin [46], streptolysin $\mathrm{O}$ [47] electro-permeabilization [48, 49], or scrape loading [50]. Electro-permeabilization of Hela cells enables the delivery of $\mathrm{C} 3$ to complete cell populations and biochemical studies on RhoA-dependent effects [34, 51].

Furthermore, the C3 gene was introduced into eukaryotic cells by transient and stable transfection with plasmids or by viral infection. Transgenic mice have also been created to specifically express C3 exoenzyme in thymocytes or lenses [52-58].

To simplify C3 handling and subsequent studies, C3 chimeras were constructed. Such chimeras make use of the delivery domains of other toxins such as diphtheria toxin, which mediates its own cell entry at low concentrations. $\mathrm{C} 3^{\text {bot }}$ has been fused to the binding and translocation subunits of diphtheria toxin [59], the binding domain of Clostridium botulinum C2 toxin [60-62], or the Tat peptide from HIV [63, 64], which are all able to permeate membranes. The application of chimeric-C3-toxins requires lower toxin concentrations (compared to the mere exoenzyme) on cell lines sensitive to either diphtheria toxin, $\mathrm{C} 2$ toxin or the tat peptide. C3 is then taken up by an identified process and the $\mathrm{C} 3$ activity occurs upon hours of treatment. However, the interpretation of findings is not as simple as initially thought because at least $\mathrm{C} 3^{\text {bot }}$ and $\mathrm{C} 3^{\lim }$ inhibit Ral signaling. Novel findings show that $\mathrm{C} 3^{\text {bot }}$ exhibits an enzyme-independent effect, at least upon neurons.

\section{THERAPEUTIC FEATURES}

Rho proteins are pivotal players in axonal growth and repair after neuronal injury that include the spinal cord [6569 ]. Injury leads to the scenario that axons make contact with growth inhibitory molecules such as myelin-associated glycoprotein (MAG) or Nogo. Thereby, via membrane receptors such as $\mathrm{p} 75^{\mathrm{NTR}}, \mathrm{NgR}$, Lingo, distinct signalling pathways are activated whose common player is RhoA. RhoA is activated through these pathways, which causes activation of Rho kinase (ROCK). Active ROCK in turn leads to growth cone collapse (at the axon tip of the or damage site), i.e. inhibition of axonal growth and blocked repair processes [70-73]. Rho inhibition may thus represent a strategy to de-block growth arrest. In fact, Rho inhibition by C3 de-blocks and allows re-growth plus repair of axons in animal models [71]. Under the assumption that $\mathrm{C} 3$ must enter its target cells, C3 fused to cell-permeable peptides has been applied in these studies. The findings with different animal models have been so convincing in enhancing recovery that cell-permeable $\mathrm{C} 3$ (BA-210) is now tested in phase II of clinical studies to treat human spinal cord injury [74].

In the meantime, we found that enzyme-deficient $\mathrm{C} 3$ induces axonal growth, excluding that ADP-ribosylation of Rho is necessary for growth promotion [75]. More recently, we found that a 29 amino acid peptide fragment of C3 is sufficient for growth promotion [76]. While enzymicallyactive C3 affects neurons as well as glial cells, the C3 peptide does not act on glial cells. This is a remarkable finding, as glial cells are thought to mediate neural inflammation and formation of glial scars in response to injury [77]. The neurotrophic effect of the C3 peptide remains uncharacterized, in particular if it depends upon binding to a cell surface receptor or neuronal uptake of the peptide.

\section{IN SUMMARY}

- C3 exoenzyme from Clostridium botulinum specifically ADP-ribosylates RhoA, RhoB, and RhoC from the Ras superfamily of low molecular weight GTP-binding proteins.

- ADP-ribosylation leads to functional inactivation of cellular Rho. 
- Because of its high substrate specificity, Rho is applied as a tool in cell biological research. Cell permeable $\mathrm{C} 3$ constructs are used.

- Cell-permeable C3 is applied as a drug to treat spinal cord injuries.

\section{REFERENCES}

[1] Aktories K, Weller U, Chhatwal GS. Clostridium botulinum type C produces a novel ADP- ribosyltransferase distinct from botulinum C2 toxin. FEBS Lett 1987; 212: 109-13.

[2] Chardin P, Boquet P, Madaule P, Popoff MR, Rubin EJ, Gill DM. The mammalian $\mathrm{G}$ protein rho $\mathrm{C}$ is ADP- ribosylated by Clostridium botulinum exoenzyme $\mathrm{C} 3$ and affects actin microfilament in Vero cells. EMBO J 1989; 8: 1087-92.

[3] Sekine A, Fujiwara M, Narumiya S. Asparagine residue in the rho gene product is the modification site for botulinum ADPribosyltransferase. J Biol Chem 1989; 264: 8602-5.

[4] Paterson HF, Self AJ, Garrett MD, Just I, Aktories K, Hall A. Microinjection of recombinant $\mathrm{p} 21^{\text {rho }}$ induces rapid changes in cell morphology. J Cell Biol 1990; 111: 1001-7.

[5] Vogelsgesang M, Pautsch A, Aktories K. C3 exoenzymes, novel insights into structure and action of Rho-ADP-ribosylating toxins. Naunyn-Schmiedeberg's Arch Pharmacol 2007; 374: 347-60.

[6] Aktories K, Just I. Clostridial Rho-inhibiting protein toxins. Curr Top Microbiol Immunol 2005; 291: 113-45.

[7] Aspenström P, Fransson A, Saras J. Rho GTPases have diverse effects on the organization of the actin filament system. Biochem $\mathbf{J}$ 2004; 377: 327-37.

[8] Etienne-Manneville S, Hall A. Rho GTPases in cell biology. Nature 2002; 420: 629-35.

[9] Wennerberg K, Der CJ. Rho-family GTPases: it's not only Rac and Rho (and I like it). J Cell Sci 2004; 117: 1301-12.

[10] Heasman SJ, Ridley AJ. Mammalian Rho GTPases: new insights into their functions from in vivo studies. Nat Rev Mol Cell Biol 2008; 9: 690-701.

[11] Vetter IR, Wittinghofer A. The guanine nucleotide-binding switch in three dimensions. Science 2001; 294: 1299-304.

[12] Bishop AL, Hall A. Rho GTPases and their effector proteins. Biochem J 2000; 348: 241-55.

[13] Burridge K, Wennerberg K. Rho and Rac take center stage. Cell 2004; 116(2): 167-79.

[14] Sehr P, Joseph G, Genth H, Just I, Pick E, Aktories K. Glucosylation and ADP-ribosylation of Rho proteins - Effects on nucleotide binding, GTPase activity, and effector-coupling. Biochemistry 1998; 37: 5296-304.

[15] Fujihara H, Walker LA, Gong MC, et al. Inhibition of RhoA translocation and calcium sensitization by in vivo ADP-ribosylation with the chimeric toxin DC3B. Mol Biol Cell 1997; 8: 2437-47.

[16] Genth H, Gerhard R, Maeda A, et al. Entrapment of Rho ADPribosylated by Clostridium botulinum C3 exoenzyme in the Rhoguanine nucleotide dissociation inhibitor-1 complex. J Biol Chem 2003; 278: 28523-7.

[17] Genth H, Schmidt M, Gerhard R, Aktories K, Just I. Activation of phospholipase D1 by ADP-ribosylated RhoA. Biochem Biophys Res Commun 2003; 302: 127-32.

[18] Aktories K, Wilde C, Vogelsgesang M. Rho-modifying C3-like ADP-ribosyltransferases. Rev Physiol Biochem Pharmacol 2004; 152: 1-22.

[19] Wiegers W, Just I, Müller H, Hellwig A, Traub P, Aktories K. Alteration of the cytoskeleton of mammalian cells cultured in vitro by Clostridium botulinum $\mathrm{C} 2$ toxin and C3 ADP-ribosyltransferase. Eur J Cell Biol 1991; 54: 237-45.

[20] Just I, Mohr C, Schallehn G, et al. Purification and characterization of an ADP-ribosyltransferase produced by Clostridium limosum. J Biol Chem 1992; 267: 10274-80.

[21] Just I, Schallehn G, Aktories K. ADP-ribosylation of small GTPbinding proteins by Bacillus cereus. Biochem Biophys Res Commun 1992; 183: 931-6.

[22] Wilde C, Vogelsang M, Aktories K. Rho-specific Bacillus cereus ADP-ribosyltransferase $\mathrm{C} 3 \mathrm{cer}$ cloning and characterization. Biochemistry 2003; 42: 9694-702.

[23] Wilde C, Chhatwal GS, Schmalzing G, Aktories K, Just I. A novel C3-like ADP-ribosyltransferase from Staphylococcus aureus modifying RhoE and Rnd3. J Biol Chem 2001; 276: 9537-42.
[24] Han S, Arvai AS, Clancy SB, Tainer JA. Crystal structure and novel recognition motif of rho ADP-ribosylating C3 exoenzyme from clostridium botulinum: structural insights for recognition specificity and catalysis. J Mol Biol 2001; 305: 95-107.

[25] Ménétrey J, Flatau G, Stura EA, et al. NAD binding induces conformational changes in Rho ADP-ribosylating Clostridium botulinum C3 exoenzyme. J Biol Chem 2002; 277: 30950-7.

[26] Foster R, Hu K-Q, Lu Y, Nolan KM, Thissen J, Settleman J. Identification of a novel human Rho protein with unusual properties: GTPase deficiency and in vivo farnesylation. Mol Cell Biol 1996; 16: 2689-99.

[27] Riento K, Guasch RM, Garg R, Jin B, Ridley A. RhoE binds to ROCK I and inhibits downstream signalling. Mol Cell Biol 2003; 23: 4119-229.

[28] Wennerberg K, Forget MA, Ellerbroek SM, et al. Rnd proteins function as RhoA antogonists by activating p190 RhoGAP. Curr Biol 2003; 13: 1106-15.

[29] Wilde C, Just I, Aktories K. Structure-function analysis of the RhoADP-ribosylating exoenzyme C3stau2 from Staphylococcus aureus. Biochemistry 2002; 41: 1539-44.

[30] Wilde C, Barth $\mathrm{H}$, Sehr P, et al. Interaction of the Rho-ADPribosylating C3 exoenzyme with RalA. J Biol Chem 2002; 277: 14771-6.

[31] Pautsch A, Vogelsgesang M, Trankle J, Herrmann C, Aktories K. Crystal structure of the C3bot-RalA complex reveals a novel type of action of a bacterial exoenzyme. EMBO J 2005; 24(20): 367080 .

[32] Just I, Boquet P. Large clostridial cytotoxins as tools in cell biology. Curr Top Microbiol Immunol 2000; 250: 97-107.

[33] Aktories K, Barth H, Just I. Clostridium botulinum C3 exoenzyme and C3-like transferases-. Handbook of Experimental Pharmacology. Berlin: Springer Verlag 2000; pp. 207-33.

[34] Huelsenbeck SC, May M, Schmidt G, Genth H. Inhibition of cytokinesis by Clostridium difficile toxin $\mathrm{B}$ and cytotoxic necrotizing factors-reinforcing the critical role of RhoA in cytokinesis. Cell Motil Cytoskeleton 2009; [in press].

[35] Ho TT, Merajver SD, Lapiere CM, Nusgens BV, Deroanne CF. RhoA-GDP regulates RhoB protein stability. Potential involvement of RhoGDIalpha. J Biol Chem 2008; 283(31): 21588-98.

[36] Jiang K, Delarue FL, Sebti SM. EGFR, ErbB2 and Ras but not Src suppress RhoB expression while ectopic expression of RhoB antagonizes oncogene-mediated transformation. Oncogene 2004; 23(5): 1136-45.

[37] Huelsenbeck J, Dreger SC, Gerhard R, Fritz G, Just I, Genth H. Upregulation of the Immediate Early Gene Product RhoB by Exoenzyme C3 from Clostridium limosum and Toxin B from Clostridium difficile. Biochemistry 2007; 46(16): 4923-31.

[38] Morii N, Narumiya S. Preparation of native and recombinant Clostridium botulinum C3 ADP-ribosyltransferase and identification of Rho proteins by ADP-ribosylation. Methods Enzymol 1995; 256: 196-206.

[39] Verschueren H, De Baetselier P, De Braekeleer J, Dewit J, Aktories K, Just I. ADP-ribosylation of Rho-proteins with botulinum C3 exoenzyme inhibits invasion and shape changes of T-lymphoma cells. Eur J Cell Biol 1997; 73(2): 182-7.

[40] Amano M, Mukai H, Ono Y, et al. Identification of a putative target for Rho as the serine- threonine kinase protein kinase N. Science 1996; 271: 648-50.

[41] Olson MF, Paterson HF, Marshall CJ. Signals from Ras and Rho GTPases interact to regulate expression of $\mathrm{p} 21^{\text {wafl/Cipl }}$. Nature 1998; 394: 295-9.

[42] Ridley AJ, Hall A. Signal transduction pathways regulating Rhomediated stress fibre formation: Requirement for a tyrosine kinase. EMBO J 1994; 13: 2600-10.

[43] Chong LD, Traynor-Kaplan A, Bokoch GM, Schwartz MA. The small GTP-binding protein Rho regulates a phosphatidylinositol 4 phosphate 5-kinase in mammalian cells. Cell 1994; 79: 507-13.

[44] Ridley AJ, Hall A. The small GTP-binding protein rho regulates the assembly of focal adhesions and actin stress fibers in response to growth factors. Cell 1992; 70: 389-99.

[45] Watanabe N, Madaule P, Reid T, et al. p140mDia, a mammalian homolog of Drosophila diaphanous, is a target protein fro Rho small GTPase and is a ligand for profilin. EMBO J 1997; 16: 304456.

[46] Mackay DJG, Esch F, Furthmayr H, Hall A. Rho- and Racdependent assembly of focal adhesion complexes and actin 
filaments in permeabilized fibroblasts: an essential role for Ezrin/radixin/Moesin proteins. J Cell Biol 1997; 138: 927-38.

[47] Fensome A, Whatmore J, Morgan C, Jones D, Cockcroft S. ADPribosylation factor and Rho proteins mediate fMLP-dependent activation of phospholipase D in human neutrophils. J Biol Chem 1998; 273: 13157-64.

[48] Stasia M-J, Jouan A, Bourmeyster N, Boquet P, Vignais PV. ADPribosylation of a small size GTP-binding protein in bovine neutrophils by the $\mathrm{C} 3$ exoenzyme of Clostridium botulinum and effect on the cell motility. Biochem Biophys Res Commun 1991; 180: 615-22.

[49] Koch G, Norgauer J, Aktories K. ADP-ribosylation of Rho by Clostridium limosum exoenzyme affects basal but not N-formylpeptide-stimulated actin polymerization in human myeloid leukaemic (HL60) cells. Biochem J 1994; 299: 775-9.

[50] Barry ST, Flinn HM, Humphries MJ, Critchley DR, Ridley AJ. Requirement for Rho in integrin signalling. Cell Adhes Commun 1997; 4: 387-98

[51] Ando Y, Yasuda S, Oceguera-Yanez F, Narumiya S. Inactivation of Rho GTPases with Clostridium difficile toxin B impairs centrosomal activation of Aurora-A in G2/M transition of HeLa cells. Mol Biol Cell 2007; 18(10): 3752-63.

[52] Fujisawa K, Madaule P, Ishizaki T, et al. Different regions of Rho determine Rho-selective binding of different classes of Rho target molecules. J Biol Chem 1998; 273: 18943-9.

[53] Hill CS, Wynne J, Treisman R. The Rho family GTPases RhoA, Rac1, and CDC42Hs regulate transcriptional activation by SRF. Cell 1995; 81: 1159-70.

[54] Caron E, Hall A. Identification of two distinct mechanisms of phagocytosis controlled by different Rho GTPases. Science 1998; 282: 1717-21.

[55] Henning SW, Galandrini R, Hall A, Cantrell DA. The GTPase Rho has a critical regulatory role in thymus development. EMBO J 1997; 16: 2397-407.

[56] Meacci E, Vasta V, Moorman JP, et al. Effect of Rho and ADPribosylation factor GTPases on phospholipase D activity in intact human adenocarcinoma A549 cells. J Biol Chem 1999; 274: 18605-12.

[57] Genot E, Cleverley S, Henning S, Cantrell D. Multiple p21ras effector pathways regulate nuclear factor of activated $\mathrm{T}$ cells. EMBO J 1996; 15: 3923-33.

[58] Maddala R, Deng PF, Costello JM, Wawrousek EF, Zigler JS, Rao VP. Impaired cytoskeletal organization and membrane integrity in lens fibers of a Rho GTPase functional knockout transgenic mouse. Lab Invest 2004; 84(6): 679-92.

[59] Aullo P, Giry M, Olsnes S, Popoff MR, Kocks C, Boquet P. A chimeric toxin to study the role of the $21 \mathrm{kDa}$ GTP binding protein rho in the control of actin microfilament assembly. EMBO J 1993; 12: $921-31$.

[60] Meyer DK, Olenik C, Hofmann F, et al. Regulation of somatodendritic $\mathrm{GABA}_{\mathrm{A}}$ receptor channels in rat hippocampal neurons: Evidence for a role of the small GTPase Rac1. J Neurosci 2000; 20: 6743-51.
[61] Barth H, Roebling R, Fritz M, Aktories K. The binary Clostridium botulinum $\mathrm{C} 2$ toxin as a protein delivery system. J Biol Chem 2002; 277: 5074-81.

[62] Barth H, Hofmann F, Olenik C, Just I, Aktories K. The N-terminal part of the enzyme component (C2I) of the binary Clostridium botulinum $\mathrm{C} 2$ toxin interacts with the binding component $\mathrm{C} 2 \mathrm{II}$ and functions as a carrier system for a Rho ADP-ribosylating C3-like fusion toxin. Infect Immun 1998; 66: 1364-9.

[63] Curnow P, Mellor H, Stephans DJ, Lorch M, Booth PJ. Translocation of the cell-penetrating Tat peptide across artificial bilayers and into living cells. Biochem Soc Symp 2005; 72: 199209.

[64] Park J, Kim JS, Jung KC, et al. Exoenzyme Tat-C3 inhibits association of zymosan particles, phagocytosis, adhesion, and complement binding in macrophage cells. Mol Cells 2003; 16: 21623.

[65] Govek EE, Newey SE, Van AL. The role of the Rho GTPases in neuronal development. Genes Dev 2005; 19: 1-49.

[66] Nadif KN, Van AL. Rho-linked genes and neurological disorders. Pflugers Arch 2008; 455: 787-97.

[67] Dickson BJ. Rho GTPases in growth cone guidance. Curr Opin Neurobiol 2001; 11: 103-10.

[68] Linseman DA, Loucks FA. Diverse roles of Rho family GTPases in neuronal development, survival, and death. Front Biosci 2008; 13: 657-76.

[69] Watabe-Uchida M, Govek EE, Van Aelst L. Regulators of Rho GTPases in neuronal development. J Neurosci 2006; 26: 10633-5.

[70] Schmandke A, Schmandke A, Strittmatter SM. ROCK and Rho: biochemistry and neuronal functions of Rho-associated protein kinases. Neuroscientist 2007; 13: 454-69.

[71] McKerracher L, Higuchi H. Targeting Rho to stimualte repair after spinal cord injury. J Neurotrauma 2006; 23: 309-17.

[72] Dubruil CI, Marklund N, Deschamps K, McIntosh TK, McKerracher L. Activation of Rho after traumatic brain injury and seizure in rats. Exp Neurol 2006; 198: 361-9.

[73] Dubreuil CI, Winton MJ, McKerracher L. Rho activation patterns after spinal cord injury and the role of activated Rho in apoptosis in the central nervous system. J Mol Biol 2003; 162: 233-43.

[74] Lord-Fontaine S, Yang F, Diep Q, et al. Local inhibition of Rho signaling by cell-permeable recombinant protein BA-210 prevents secondary damage and promotes funtional recovery following acute spinal cord injury. J Neurotrauma 2008; 25: 1309-22.

[75] Ahnert-Hilger G, Höltje M, Große G, et al. Differential effects of Rho GTPases on axonal and dendritic development in hippocampal neurons. J Neurochem 2004; 90: 9-18.

[76] Holtje M, Djalali S, Hofmann F, et al. A 29-amino acid fragment of Clostridium botulinum $\mathrm{C} 3$ protein enhances neuronal outgrowth, connectivity, and reinnervation. FASEB J 2008; 23: 1115-26.

[77] Holtje M, Hofmann F, Lux R, Veh RW, Just I, Ahnert-Hilger G. Glutamate uptake and release by astrocytes are enhanced by Clostridium botulinum C3 protein. J Biol Chem 2008; 283: 928999. 